\title{
THE USE OF ICT IN THE DELIVERY OF ONLINE SERVICES
}

\author{
and its impact on student satisfaction at RMIT University
}

\author{
Kevin Leung, John Byrne, France Cheong \\ School of Business Information Technology, RMIT University, Melboume, Australia \\ kevin.letung@rmit.edu.au
}

\begin{abstract}
With the changing role of the student from participant to customer, universities should examine their level of customer service. Using a questionnaire adapted from the Student Satisfaction Inventory (SSI), this study assessed the differences in expectations, as examined by importance scores, satisfaction scores, and performance gap scores of RMIT Business undergraduate students in regard to the technological services provided by the university. A random sample of final year Business undergraduate students was surveyed and an analysis was performed to determine how student satisfaction was affected by student online services delivered through the use of Information and Communication Technologies (ICT).
\end{abstract}

Key words: Higher education, satisfaction, online services, technology.

\section{INTRODUCTION}

In recent years, one of the main concerns in universities has been student satisfaction. The concept of student satisfaction is becoming increasingly important among institutions of higher learning. The customer service approach towards students that universities are using today focuses on meeting demands and expectations of students and fostering overall satisfaction (Astin 1993; Orpen 1990).

Product and service marketers know that in order to keep customers, they must offer high quality service (Dabholkar, Shepherd \& Thorpe 2000). This is the reason why student services must keep abreast of changing student needs in order to provide quality services and ensure continued student 
satisfaction. Moneta (1997) has found that today's students are 24 hours, 7 day-a-week customers who reject the service disadvantages of traditional 9-5 business practices and expect campuses to become a 24 hour domain.

The integration of technology in student services (e.g. admissions, advising, financial aid, orientation, etc.) has the benefit of improving service delivery. Tinto (1987) explained that integrating student service processes will allow the coordination and efficient grouping of often disparate activities to produce services which are in effect, greater than the sum of their separate parts. Moreover, Beede and Burnett (1999) argued that the traditional model of functional silos, lines and multiple offices, limited access and bureaucratic paper-driven process will have to be replaced with the new model of anytime-anyplace (24/7) access and one source of electronic data.

It is clear that technology plays an important part in the delivery of student services. It is equally clear that institutions will need to have a strategic plan for integrating technology in student services. But what should remain first and foremost in every decision made is the institution's commitment to the student (Karla 2002). As such, the mission of higher education is not only to impart knowledge but also to provide reliable, student-oriented services in a way to enhance the student's total development (Astin 1993). One of the ways higher education institutions accomplish this mission is by continuously collecting information on student satisfaction.

\section{METHODOLOGY}

\subsection{Questionnaire}

In order to evaluate the levels of expectations and satisfaction of RMIT Business students, a questionnaire was designed. It was based on the Student Satisfaction Inventory (SSI), which was produced by USA Group NoelLevitz (2000) and whose purpose is to collect basic demographic information about respondents and measure student perceptions regarding both the importance of, and satisfaction with, key student services and campus experiences in traditional campus environments. However, since the SSI is designed for traditional higher education settings, not all of the scales or survey questions may be relevant to student online services. Five SSI scales (out of twelve) are composed of items that most directly address student services and they were further classified into three different dimensions as shown in table 1. 
Table 1. Dimensions and SSI Scales

\begin{tabular}{ll}
\hline Dimension & SSI Scales \\
\hline Course Related & Academic Advising and Counselling \\
& Effectiveness \\
Academic Administration and Registration & Registration Effectiveness \\
General University & Recruitment and Financial Aid Effectiveness \\
& Service Excellence \\
& Campus Support Services
\end{tabular}

\subsection{Population and Sample}

The target population for this study consisted of RMIT business undergraduate students. However, participation in the survey was restricted only to final year students due to the fact that they had adequate experience to rate the statements in the questionnaire.

To appropriately conduct tests of statistical significance, the issue of sample size is important (Hinkin 1995). The results of many multivariate analysis techniques depend significantly on sample size. Considering these arguments and also time and resource constraints, the sample size chosen for this study was 135 respondents. The sample was obtained using a stratified sampling method. In this method, the sample is not only chosen randomly, but it is also made to reflect the population in some specified characteristic (Petocz 1990). Table 2 shows how the sample size was obtained.

Table 2. Sample Size

\begin{tabular}{llcc}
\hline School & Business Programs & $\begin{array}{c}\text { \% Target } \\
\text { Population }\end{array}$ & $\begin{array}{c}\text { Size of Random } \\
\text { Sample }\end{array}$ \\
\hline Accounting and Law & Accountancy & $19 \%$ & 26 \\
Business Information & Business Information & $34 \%$ & 46 \\
Technology & Systems & & \\
Economics and Finance & Economics and Finance & $19 \%$ & 26 \\
Management & Business Administration & $9 \%$ & 12 \\
Marketing & Marketing & $11 \%$ & 14 \\
& Transport and Logistics & $8 \%$ & 11 \\
& Management & & $\mathbf{1 3 5}$ \\
\cline { 2 - 3 } & Total & \multicolumn{2}{|}{} \\
& & & \\
\end{tabular}

\subsection{Email}

The questionnaire was emailed to 135 students by using their university student email addresses. Along with each questionnaire, each respondent was given an informed consent form outlining the research study and indicating that their participation was completely voluntary, their responses 
would be confidential and anonymous, and that results would only be reported in aggregate form. If the student agreed to participate in the study, he/she was expected to send back the completed questionnaire to the researcher via email. A response rate of $49.6 \%$ was obtained.

\subsection{Data Analysis}

\subsubsection{Expectation and Satisfaction Scores}

The data that was obtained from the questionnaire were the "course related", "academic administration and registration", and "general university" expectation and satisfaction scores. The sum and average of these scores were then calculated.

\subsubsection{Weights of Dimensions}

The weights of the three dimensions, were obtained by a process called the analytic hierarchy process (AHP), which was developed by Thomas (1980) and designed to solve complex problems involving multiple criteria. This process requires the respondents to provide judgments about the relative importance of each dimension and then specify a preference on each dimension for each decision alternative (Anderson, Sweeney \& Williams 1994). "Pairwise comparisons are fundamental building blocks of AHP" (Anderson et al. 1994;pp. 664). In establishing the priorities for the three dimensions, respondents were asked to state a preference for a dimension when the dimensions were compared two at a time (pairwise).

\section{RESULTS}

An examination of the level of expectation of respondents based upon their gender revealed that females had higher expectation level than males in all three dimensions. Also, the data analysis indicated that the level of expectation increased with age and this was, indeed, what Hess (1997) discovered in his study of first year and older students. It could be concluded that the respondents viewed these student online services as an integral part of their university experience and that there was a current changing role of student from participant to customer.

With regard to the respondents' level of satisfaction, it could be concluded that most participants were at least satisfied with the RMIT student online services. This is also important for administrators to note 
because with the respondents' perception in this range, the university may need to make only small changes to its student online services to improve the level of satisfaction of students.

The performance gap score is important because it provides information about unmet student expectations. When using this questionnaire in this study, it is important to note that the smaller the performance gap score, the more effectively the institution (RMIT University) is meeting its students' needs. In this study, the data analysis indicated that the smallest performance gap score (5.01) was recorded for Business Administration students while the largest performance gap score (8.66) was obtained for Business Information Systems (BIS) students. The reason why BIS students recorded a larger performance gap score compared with the others could probably be explained by the fact that BIS students are more used to technology, and as such have higher expectations and lower satisfaction.

\section{CONCLUSION}

In general, RMIT students have higher level of expectation than satisfaction, meaning that students' needs are not being fully met. Within the past few years, the general public has been bombarded with advertising that stresses customer service. Typically, higher education institutions do not treat their students as customers, but rather as partners in the educational process (Carilli 2000). This may be one of the reasons that students are not as satisfied as one would hope with their experience at RMIT University. As Levine (1999) stated in his keynote address at the First-Year Experience Conference:

"Students want a different relationship with their universities. They want convenience, and efficient and friendly service, similar to what they receive at a bank."

A limitation to this study is that it focused on only one faculty, that is, RMIT Business Faculty and as such, the conclusions of this study cannot be generalized to other faculties of the university. The results of this study may also be the product of a perception that students may have regarding their peers and the institutions they choose to attend.

Finally, it is hoped that this paper would stimulate more research in the antecedents and consequences of student satisfaction on universities' online services. A qualitative study as a follow-up would be useful as it may provide additional information about the impact of student online services on student satisfaction. 


\section{REFERENCES}

Anderson, DR, Sweeney, DJ \& Williams, TA 1994, An Introduction to Management Science: Quantitative Approaches to Decision Making, Seventh edn, West, New York.

Astin, AW 1993, What matters in college?, Jossey-Bass, San Francisco.

Beede, M \& Burnett, D 1999, Planning for student services: Best practices for the 21st century, Society for College and University Planning, Ann Arbor, MI.

Carilli, V 2000, 'Student Satisfaction at Southern Illinois University Carbondale', Southern Illinois University Carbondale.

Dabholkar, PA, Shepherd, CD \& Thorpe, DI 2000, 'A comprehensive framework for service quality: An investigation of critical conceptual and measurement issues through a longitudinal study', Journal of Retailing, vol. 76, no. 2, pp. 139-73.

Hess, EC 1997, 'Students' satisfaction with college life and implications for improving retention through counseling and institutional change', Doctoral dissertation thesis, Walden University.

Hinkin, TR 1995, 'A Review of Scale Development Practices in the study of Organizations', Journal of Management, vol. 21, no. 5, pp. 967-88.

Karla, JM 2002, 'Optimal integration of technology in student services', Pepperdine University.

Levine, A 1999, 'Today's college students keynote address', paper presented to First-Year Experience Conference, Columbia, SC.

Moneta, L 1997, 'The integration of technology with the management of student services', New Directions for Student Services, vol. 78, pp. 5-16.

Orpen, C 1990, 'The measurement of student satisfaction: A consumer behavior perspective', Journal of Human Behavior and Learning, vol. 7, no. 1, pp. 34-7.

Petocz, P 1990, Introductory Statistics, Thomas Nelson Australia.

Thomas, LS 1980, The Analytic Hierarchy Process, McGraw-Hill, New York.

Tinto, V 1987, Leaving college: Rethinking the causes and cures of student attrition, University of Chicago Press, Chicago.

USA Group Noel-Levitz 2000, Student satisfaction inventory, Author, Lowa City. 